Journal

of Geography

Politics and Society

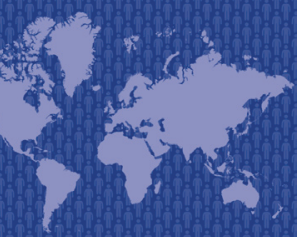

$9(4) / 2019$

\section{Journal of Geography, Politics and Society}

2019, 9(4), 42-50

https://doi.org/10.26881/jpgs.2019.4.05

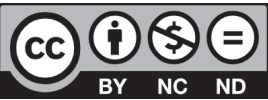

\title{
DEPOPULATED LOCALITIES OF FORMER EAST PRUSSIA AS ISOLATED COMPONENTS OF THE LANDSCAPE STRUCTURE IN THE FORM OF CLUSTERS OF HIGH VEGETATION
}

\author{
Anna Majewska \\ Department of Political and Historical Geography and Regional Studies, Faculty of Geographical Sciences, University of Lodz, Kopcińskiego 31, 93-222, Łódź, \\ Poland, ORCID: 0000-0003-0589-6400 \\ e-mail: anna.majewska@op.pl
}

\section{Citation}

Majewska A., 2019, Depopulated localities of former East Prussia as isolated components of the landscape structure in the form of clusters of high vegetation, Journal of Geography, Politics and Society, 9(4), 42-50.

\begin{abstract}
The article is devoted to selected issues concerning the contemporary landscape identity of completely deserted localities situated in the part of former East Prussia incorporated into Poland. It presents conclusions drawn from an analysis of cartographic materials and on-site research on high greenery's participation in and importance to the creation of the landscape of uninhabited settlement units. High greenery is one of the main components of the space of abandoned localities in the research area. In total, $94 \%$ of completely deserted settlements in the Polish part of former East Prussia are partially or completely covered with high greenery. Relatively often - in 39\% of all uninhabited localities - high greenery forms isolated patches in the landscape structure. This is reflected in the process of observation of both the horizontal and vertical landscape structure of a locality, as demonstrated on the example of the case study of one of the old settlements.
\end{abstract}

\section{Key words}

deserted villages, rural settlement, LiDAR, GIS, historical geography, archaeology of the contemporary past, forestation.

\section{Introduction}

The landscape of every uninhabited settlement unit is a multi-layered structure, resembling a palimpsest, consisting of many types of objects that have a different genesis and morphology. They are the material record of processes and events in the geographical space. As such, they create a material memory of the landscape of deserted localities (vide MygaPiątek, 2015; Kobiałka et al., 2015). And flora is one of the main components of this memory.
The results of geographical and historical research conducted in the part of former East Prussia incorporated into Poland in 1945 showed the significant role of flora in co-creating the contemporary landscape of uninhabited settlement units located in this area. On-site observation and identification of individual elements of the vertical landscape structure of several dozen abandoned settlements turned out to be particularly valuable. As a result, four components of depopulated localities were distinguished, being the most important elements of the memory of their 
landscape: greenery, homesteads, cemeteries, and military objects. This elaboration focuses on selected issues concerning the first of the distinguished components. The main objective was to determine the significance and share of high greenery in the creation of the landscape of depopulated localities situated in the Polish part of former East Prussia.

Why greenery? Apart from numerous social factors (including political and economic factors), the formation of the settlement network of the research area was influenced, among other things, by the specific local characteristics of the natural environment. The localities that are uninhabited today are both mid-forest villages that had been established for purposes such as peat extraction, tree felling, or charcoal production, and Warmia's reclusive settlements established on morainic hills including the beautifully exposed planning schemes of manor farms and manor houses. However, after the continuity of habitation was interrupted, the environmental conditions that had previously been important to the functioning of a locality, including the nearby raw material resources, lost their significance. In turn, this state of affairs has been beneficial to some types of physiographical objects, particularly, the flora, which - in the context of the occurring processes related to the destruction of material structures of rural systems - has become one of the leading elements in landscape identification of deserted settlements.

Vegetation is a common component of the landscape of rural settlement units. Rural planning schemes are co-created especially by home orchards and gardens, which co-determine their 'rurality' they build the genius loci of a settlement. After the continuity of habitation is broken, particularly in the face of partial or far-reaching destruction of residential and farm buildings, the former home-adjacent greenery starts to assume the role of the primary landscape distinguishing feature of the space of the depopulated locality. In almost all of such localities as a result of reduced anthropopressure - a gradual, uncontrolled succession of vegetation occurs: above all, low and medium vegetation (grasses and shrubs), including synanthropic species, among others, apophytes (e.g. Elymus repens). Self-sown plants appear. High greenery expands, which consists of fruit trees as well as old home-adjacent and roadside plantings of broadleaved trees. Vegetation extends its reach, entering areas previously used, e.g., for farming purposes. In other areas, it increases its share. Of course, such processes occur when the space of the locality is not subject to further, intensive anthropogenic transformations, e.g., those related to a change in the function of land - e.g. degradation of a former settlement in order to create arable land.

High greenery is a particularly important factor in the assessment of the vertical structure of the landscape of depopulated localities. It allows the space of a settlement to remain legible despite the passage of decades, creating one of the landscape's dominant, significant features. Contrary to what may seem to be the case, as time passes, an abandoned settlement may be distinguishable within the landscape structure due to forestation and growth of monumental specimens of trees and complexes of old trees (especially if the forestation forms isolated islands surrounded by arable fields or wastelands). But changes in the flora also constitute factors that limit the possibilities of identification of other remnants of rural planning schemes. They show transformations of the cultural landscape over time, but effectively hinder access to the still-existing surface relics, such as residential buildings.

Analyses of forest area changes occurring within and around inhabited settlement units as well as in post-depopulation conditions have been the subject of numerous studies, mainly in the field of geographical sciences (vide inter alia: Affek, 2016; Wardell et al., 2003; Poyatos et al., 2003). Analyses in this scope also accompany archaeological elaborations, especially those concerning contemporary times (vide, e.g., Domagała, 2016). The succession of vegetation in the areas of uninhabited settlements is an important aspect of landscape changes ${ }^{1}$ that happen within them after anthropopressure has weakened or almost completely ceased (vide Affek, 2011; Wolski, 2007). Vegetation co-defines a new spatial identity of the locality, and creation of this identity begins when the place becomes completely deserted.

\section{Materials and methods}

In order to determine the share and significance of high greenery in the creation of the contemporary landscape of depopulated localities situated in the Polish part of former East Prussia, an analysis of cartographic materials was carried out: the most up-todate orthophotomaps and satellite images (from the resources of: the Geoportal web service - data of the Head Office of Geodesy and Cartography (GUGiK) from 2016-2018; the Google Earth platform - the

\footnotetext{
1 The processes of changes in the reach of particular forms of land coverage are commonly taken into consideration in studies on cultural landscape transformations (e.g. Sobala, 2012).
} 
Copernicus/Landsat data collection from 20172019). On the orthophotomaps, the spaces of depopulated localities were identified, which had been found thanks to the prior progressive comparative analysis of archival $^{2}$ and current cartographic materials. Then, the share of high greenery in the horizontal landscape structure of uninhabited settlements as well as its morphological character were determined.

In the detailed elaboration, concerning the space of a single locality, the 'case study' method was applied, in which measurement data from airborne laser scanning were used. The data come from a flyover carried out as part of the governmental project named ISOK (IT System for Protecting the Country against Emergencies), and were made available under a license from GUGiK (Head Office of Geodesy and Cartography) - point cloud in the LAS format, number N-34-75-B-a-3-2-2. In order to prepare these data, GIS techniques and tools were used, including visualization and processing of ALS data by the SAGA GIS and FugroViewer programs. These techniques made it possible to distinguish ground relics of the former rural planning scheme.

\section{Results}

During on-site prospection, vegetation was often the first hint in the process of identification of depopulated rural settlement units. In most cases, other landscape components of uninhabited settlements would be noticed later: relics of various types of buildings located within homesteads and in their vicinity, or accompanying infrastructure (e.g. preserved small farm objects such as wells and home cellars). Subsequent stages in the identification of depopulated localities in a vertical and horizontal perspective of observation of landscape structures are presented in fig. 1.

On-site observations carried out by the Author allowed to conclude that greenery, mainly high greenery (trees being $>4 \mathrm{~m}$ high), which occurs in the form of clusters of old broadleaved trees, is one of the main landscape attributes of abandoned localities. This is particularly true for those of them that have a small spatial reach and are of the reclusive settlement type, located among agricultural lands (usually large arable fields and fallow land) and often on elevated terrain. Such settlement units, which are tree-covered mid-field islands, are easily identifiable in the landscape, in both the horizontal and

\footnotetext{
2 Sheets of the Topographische Karte Messtischblatt map from the 1920s-1940s, at a scale of 1:25,000.
}

vertical perspectives (cf. Fenyk, Kuszewska, 2010, p. 62). In total, $94 \%$ (741) of completely deserted settlements found in the Polish part of former East Prussia are partially or completely covered with high greenery. Nearly 39\% (308) of the depopulated localities identified in the course of research works are clusters of high greenery isolated in the landscape (fig. 2 - A). Of these, 75\% (232) are small rural settlement units with a single manor house (mainly manor houses and manor farms) (fig. 2). However, it should be emphasized that the proportion of singlemanor-house localities to the total number of localities identified as isolated patches of high vegetation corresponds to the share of all single-manor-house localities in the total number of depopulated settlements (where they constitute 74\%). Taking this into account, the spatial distribution of the localities that stand out from the space as clusters of vegetation is not surprising, because their concentration is noticeable in the northern part of the research area. In that part, there is the largest number of reclusive localities. There is a clear disproportion to the southern region, where only a few localities isolated in the landscape thanks to high greenery were recorded. This is justified by the high share of densely forested areas in this part of the research area, and a low share of agricultural areas. Therefore, depopulated localities are rarely exposed as islands in the geographical space there (with vegetation being the distinguishing feature).

The isolated clusters of high greenery, which distinguish the spaces of deserted localities, have very diverse shapes not always identical to the reach of the entire area of the former settlement unit. Most often, they form complexes of smaller clusters of vegetation, which mark the locations of individual degraded homesteads or their parts (examples fig. 3). In the case of small localities (especially planning schemes of a single manor house or a single homestead), the clusters often have regular shapes similar to the former reach of the farms (fig. 4).

The importance of high greenery as one of the main elements that co-create the contemporary landscape of depopulated settlement units has been detailed on the example of the former locality named Petersbruch (Sztum County, Warmia-Masuria Voivodeship) (fig. 5). The abandoned locality is situated in the historical region of Upper Prussia. Until 1939, the settlement consisted of 5 homesteads ( $2-3$ buildings in each farm), distributed irregularly on both sides of the road. In the north-western part of the locality, there was also a small cemetery (fig. 8). Nowadays, the whole area of the settlement is a $420 \mathrm{~m} \times 150 \mathrm{~m}$ patch isolated from the surrounding landscape. This area is covered with vegetation, 

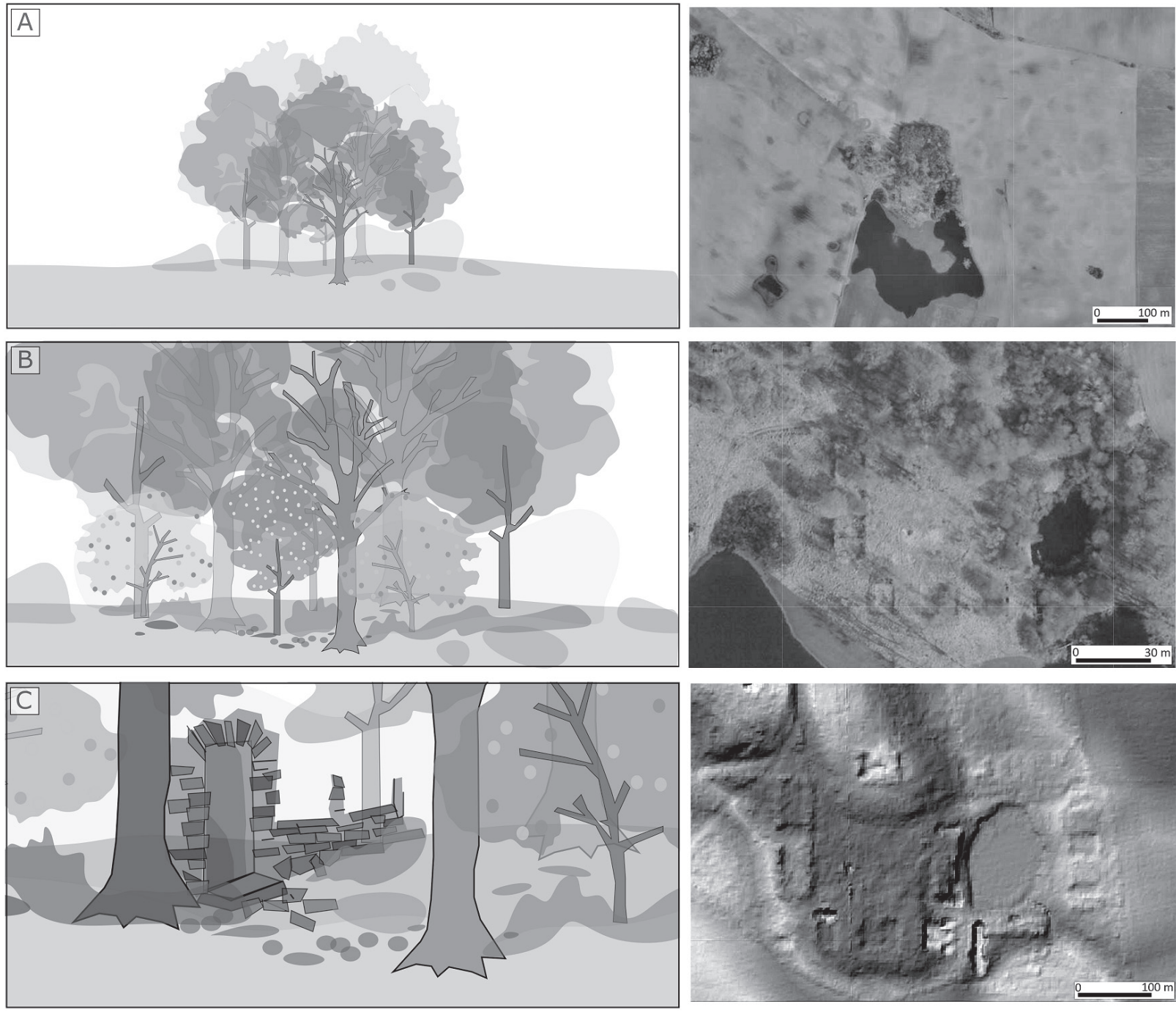

Stages of identification in a vertical and horizontal perspective of observation of landscape structures:

- long distance - the space of the locality as an isolated, tree-covered island;

- shortened distance - perceptible details of vegetation, including identifiable old plantings and, partly, relics of infrastructure;

- within the deserted locality - identifiable details of the relics of buildings, in a horizontal perspective, identification possible through ALS derivatives (points on the ground surface) (in the cartographic visualizations, a locality with a single manor house - the Kloben manor farm, Olsztyn County, Świątki Commune).

Fig. 1. Role of vegetation in the identification of the spaces of depopulated localities - a diagram Source: own elaboration.

where high greenery has the highest share $(>4 \mathrm{~m})$. The contour map, prepared based on measurement data from airborne laser scanning (data in LAS format, source: the ISOK project, GUGiK), which provides for the class of points on the surface of the ground (class No. 2) as well as classes of vegetation (classes No. 3, 4, and 5), clearly shows the isolation of the area of the locality in the geographical space. The immediate surroundings are arable fields (vide fig. 5, contour map - fig. 6).

Additionally, elevational sections were made through the point cloud in $25 \mathrm{~m}$-wide strips, in order to determine the differences in relative heights between the area of the locality and the adjacent area (fig. 7). In this case, vegetation is the component that distinguishes the area of the locality from the surrounding area also in the vertical perspective of observation of landscape structures. The trees in this area have a height of up to $23 \mathrm{~m}$ (vide fig. 7).

Only later - 'inside' the locality's landscape - is it possible to notice other elements that create it, such as the remnants of destroyed buildings and other traces of anthropogenic activity, which, in this case, were identified through airborne laser scanning derivatives (point class: ground) (vide fig. 8). Apart from the remnants of buildings, in the village there are 

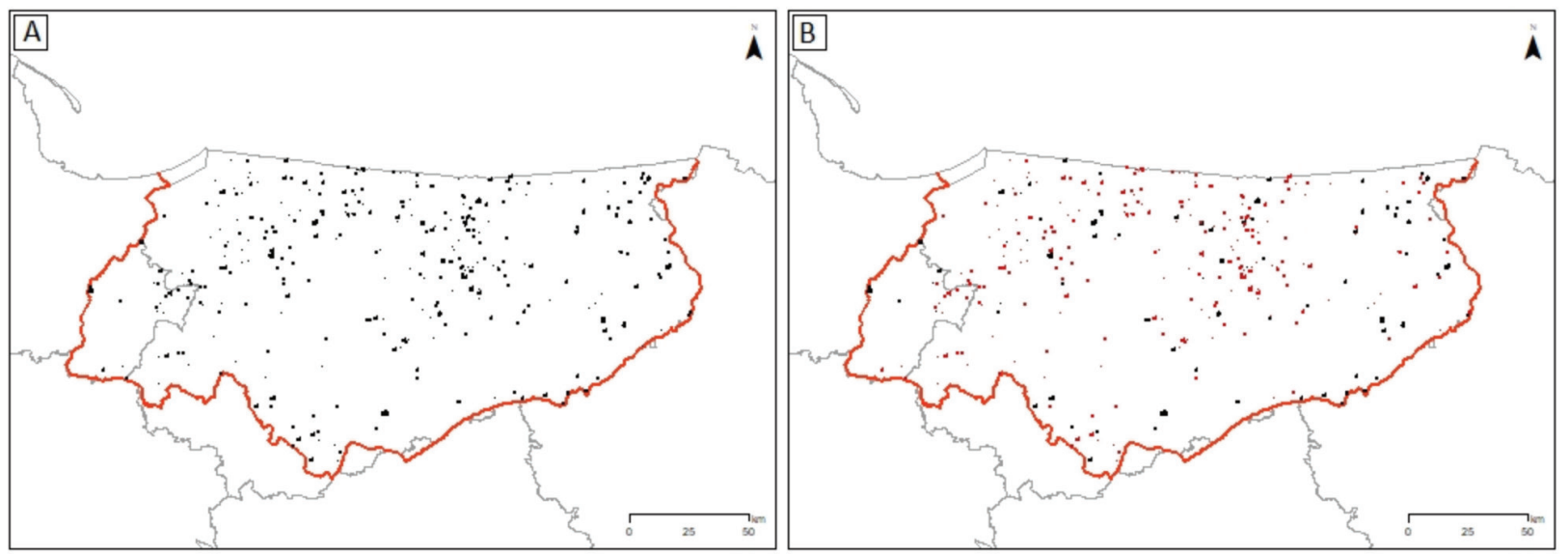

Fig. 2. Completely deserted localities in the part of former East Prussia incorporated into Poland, whose structures stand out from the landscape as isolated clusters of high greenery - all together (A); single-manor-house localities marked in red (B) Source: own elaboration.

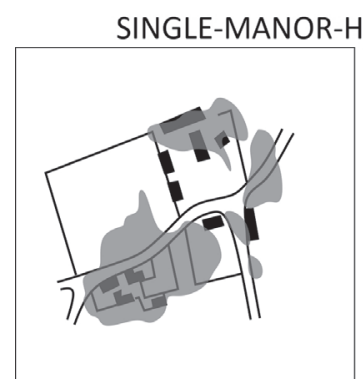

Werder (Gut)

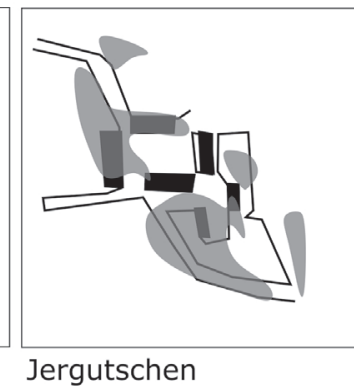

Jergutschen

$100 \mathrm{~m}$

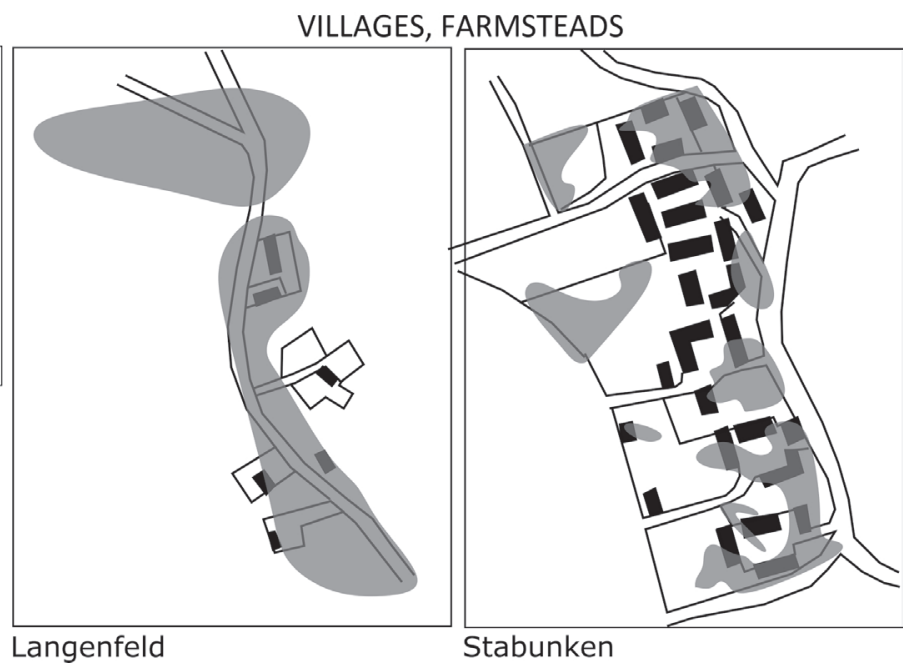

Fig. 3. Reach of clusters of high greenery that co-create the areas of depopulated localities - examples

Source: own elaboration based on contemporary orthophotomaps: GUGiK, 2016; the Topographische Karte Messtischblatt archival map at a scale of $1: 25,000$, sheets: 1695 - Nordenburg, 1933; 1797 - Buddern, 1927; 1694 - Wandlacken, 1940; 1788 - Landsberg, 1936.
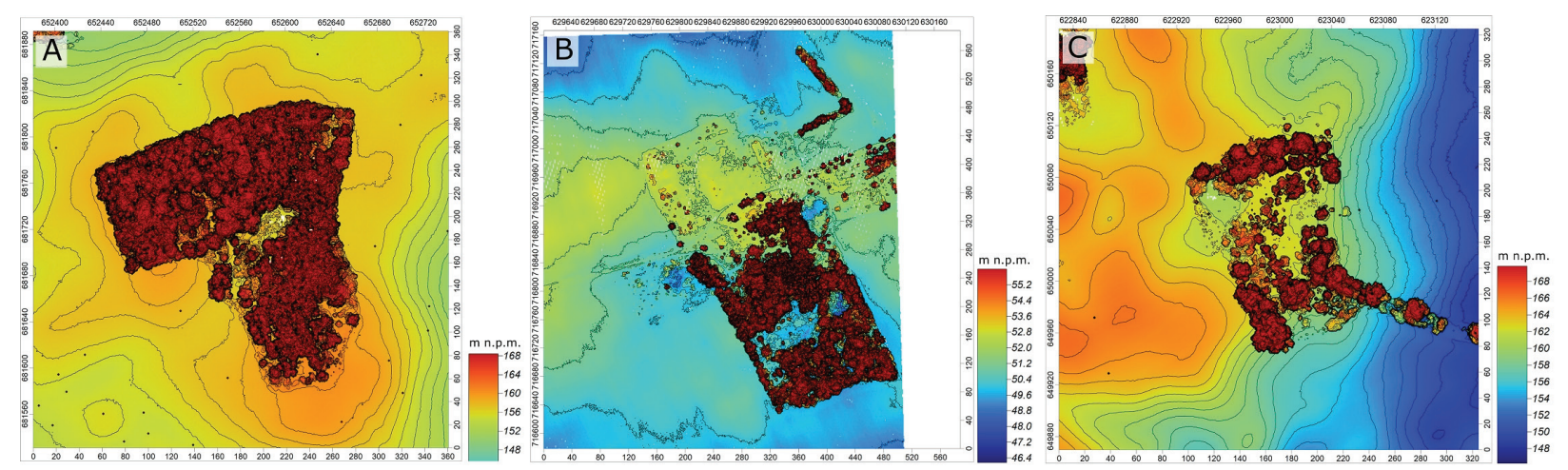

Contour maps prepared on the basis of ALS data (point classes: ground, low, medium, high vegetation) (A - Paulsfelde: Mrągowo Commune, B - Rohden: Sępopol Commune, C - Charlotten, Pasym Commune)

Fig. 4. Clusters of high vegetation with a regular outline, which mark the areas of selected localities that have a single manor house

Source: own elaboration, data: GUiK, LAS sheets: N-34-79-B-a-2-3-1, N-34-66-B-b-2-4-4; N-34-78-D-c-4-2-2. 


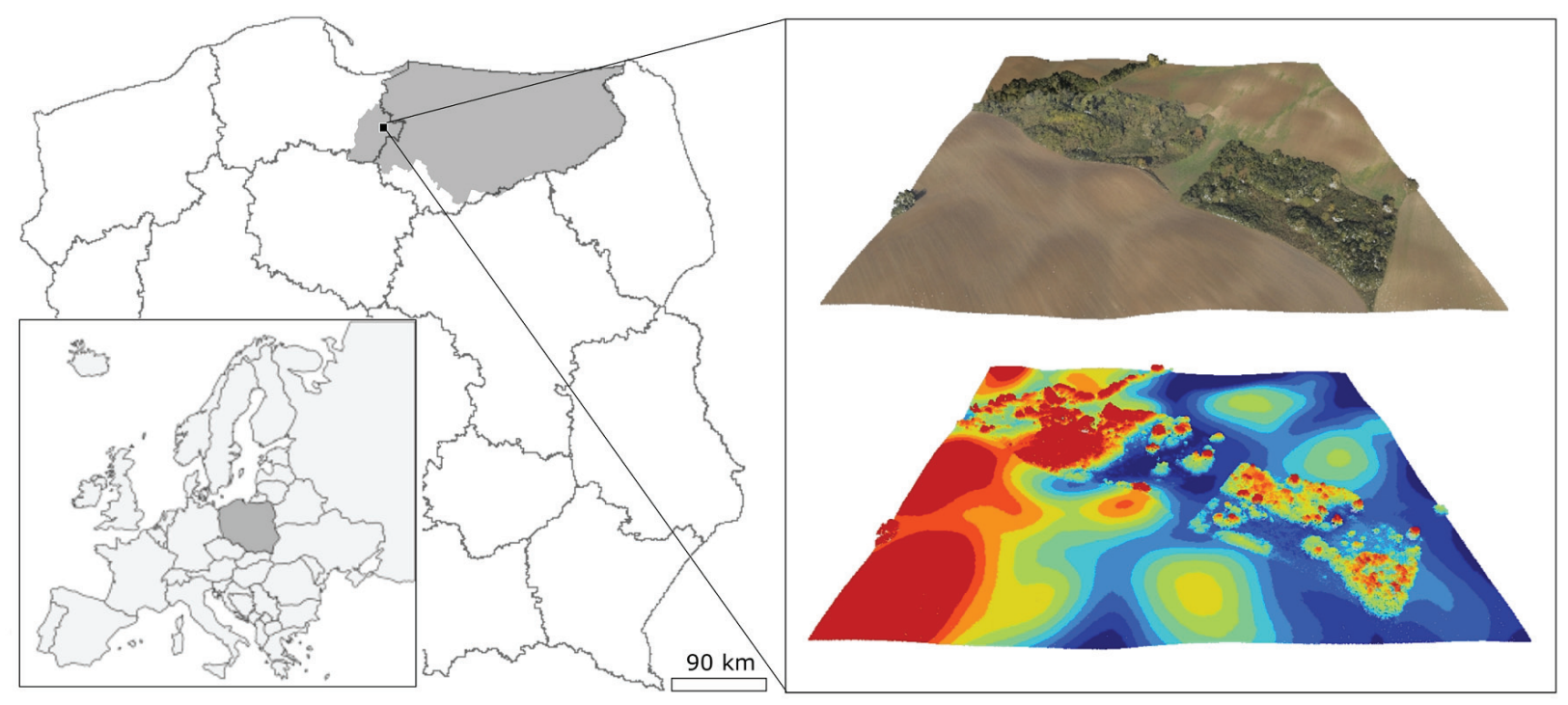

Fig. 5. Situation of the depopulated locality named Petersbruch (Sztum County, Dzierzgoń Commune). The locality in a $3 \mathrm{D}$ visualization of the point cloud (oblique projection) (RGB coloration and elevation coloration)

Source: own elaboration, LAS measurement data, sheet: n-34-75-B-a-3-2-2.

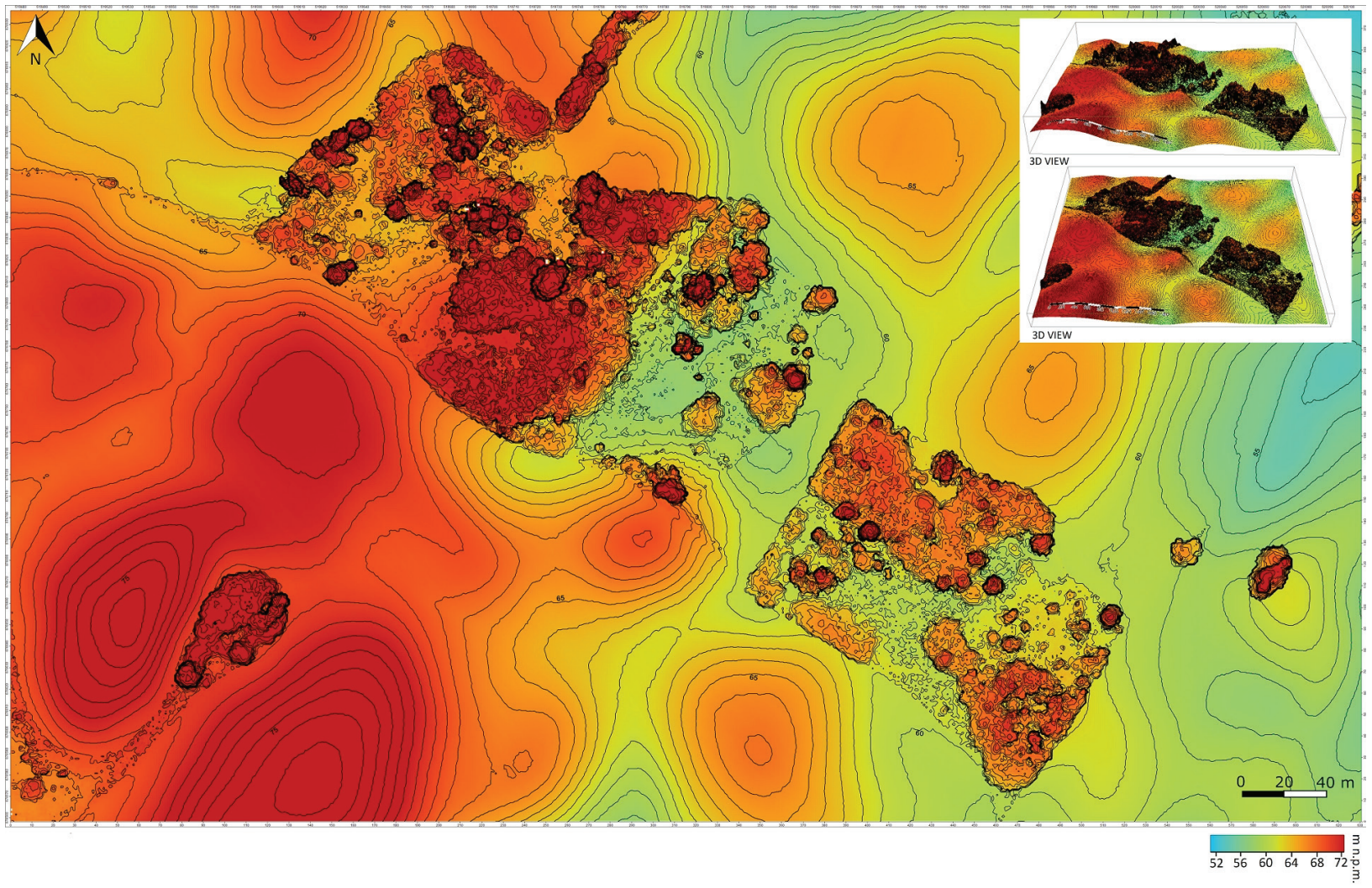

Fig. 6. Space of the depopulated locality named Petersbruch (Sztum County, Dzierzgoń Commune) as a complex of isolated clusters of high vegetation. Contour map of land coverage, prepared based on LiDAR measurement data (providing for the following point classes: ground surface; low, medium, and high vegetation), on a color scale, contour interval $1 \mathrm{~m} ; 0.25 \mathrm{~m}$

Source: own elaboration based on DTM measurement data - ISOK, GUGiK, sheet: N-34-75-B-a-3-2-2. 

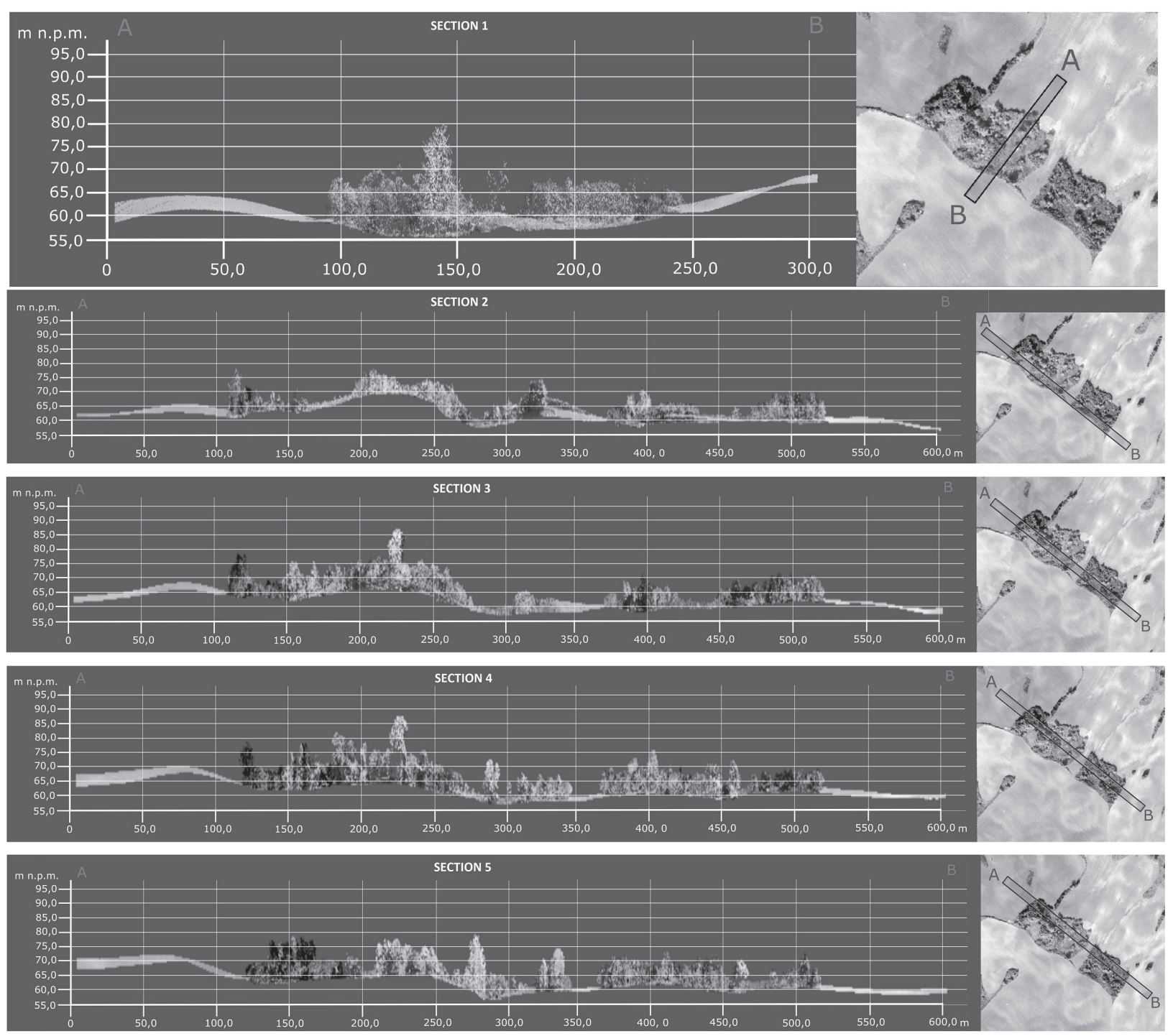

Fig. 7. Petersbruch (Sztum County, Dzierzgoń Commune) - elevational sections made through the point cloud (ground surface and vegetation) in RGB coloring (width of the sections: $25 \mathrm{~m}$, exaggeration of the vertical dimension: $2 x$ )

Source: own elaboration, ISOK data, GUGiK, LAS measurement data, sheet: n-34-75-B-a-3-2-2.

various types of hollows resulting from human activity, relics of embankments and border ditches of individual homesteads, the earth mound of the local cemetery. The sunken lanes of roads remain legible.

\section{Conclusions}

High greenery is one of the main components determining the contemporary identification of the landscapes of depopulated localities in the Polish part of former East Prussia. In total, $94 \%$ of completely deserted settlements of the research area are partially or completely covered with high greenery. Relatively often - in 39\% of all uninhabited localities - high greenery forms isolated patches in the landscape structure. These are mainly the remnants of old plantings which, over time, got supplemented with self-sown plants as well as home garden plants, ornamental plants, and ruderal species that colonized the adjacent areas. With simultaneous (mainly agricultural) exploitation of the adjacent areas, the uninhabited settlements get exposed in the landscape, which fact usually remains apparent in both vertical and horizontal imaging. An example of this is the discussed case study - material relics of a locality that have their own terrain forms, such as architectural remnants, being the elements of the 'landscape interior' of a deserted locality. When recognizing its contemporary structure, the component that gets observed first is the layer of greenery. The flora, being a part of the memory of the landscape in depopulated localities, has a twofold character. It is both a relic element, which shows the functioning of a locality 


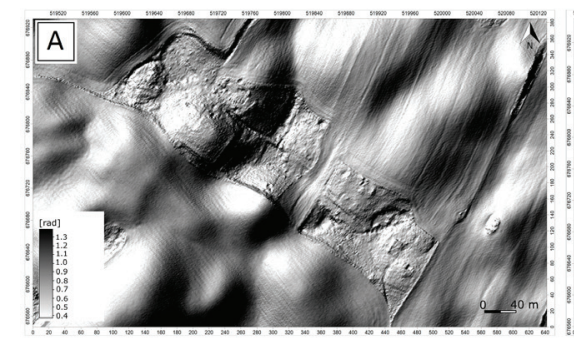

D

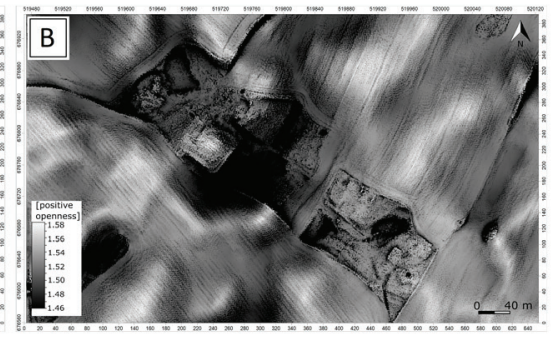

E

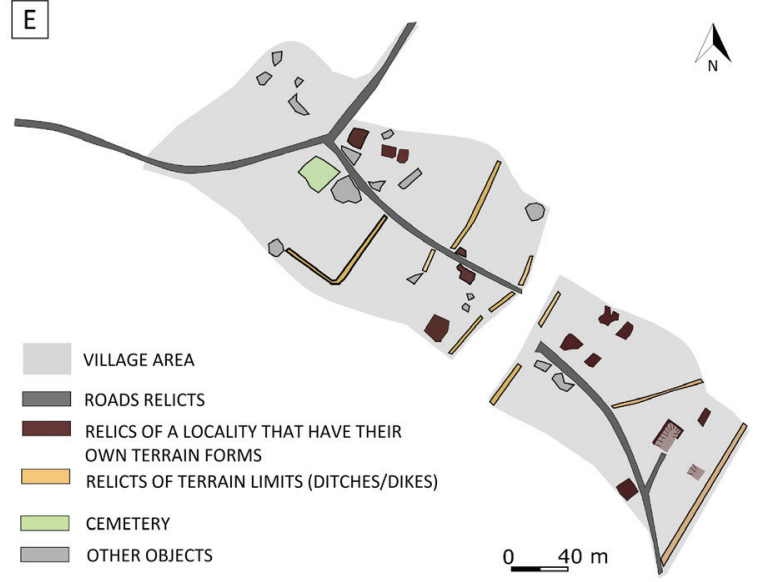

Visualization variants of the lay of the land: digital terrain models (GRID) developed based on point class No. 2 with a drawn interpretation of the locality's relics:

A - DTM (GRID): visualization of the lay of the land, with directional lighting, relief in grayscale;

B - DTM (GRID): visualization of the lay of the land using the positive openness algorithm (which exposes ground elevations);

C - DTM (GRID): visualization of the lay of the land using the negative openness algorithm (which exposes ground depressions);

$D$ - reach of the main clusters of high greenery in the settlement;

$\mathrm{E}$ - interpretation of the locality's space based on elaborations of ALS data; objects of anthropogenic origin having their own terrain forms.

Fig. 8. The deserted locality of Petersbruch in elaborations of data from airborne laser scanning

Source: ISOK, GUGiK, LAS measurement data, sheet: N-34-75-B-a-3-2-2.

when it was still inhabited, and a material proof of the processes and events that took place after the continuity of habitation had been interrupted.

\section{Funding acknowledgment}

Research carried out as a part of the research project entitled "Memory of the Landscape of Localities Declining from the Area of the Former East Prussia the Material Dimension of the Broken Continuity of Settlement" (registration number: 2018/29 / N / HS3 / 01001), financed by the National Science Centre (Poland) as part of the Preludium grant competition 15 and the doctoral dissertation arising there from.

\section{References}

Affek A., 2011, Wartości krajobrazu opuszczonego przez ludność na przykładzie byłej Rusińskiej wsi Borysławka (Eng. Values of landscape abandoned by people. A case study of former ruthenian village Borysławka), Prace Komisji Krajobrazu Kulturowego. Niematerialne wartości krajobrazów kulturowych, 15, 148-160.

Affek A., 2016, Dynamika krajobrazu: uwarunkowania i prawidłowości na przykładzie dorzecza Wiaru w Karpatach (XVIII-XXI wiek) (Eng. Landscape dynamics: determinants and patterns on the example of the Wiar river basin in the Carpathians (18th-21th century), Instytut Geografii i Przestrzennego Zagospodarowania PAN, Warszawa.

Domagała S., 2016, Archeologiczne krajobrazy współczesności. Co z nas zostanie po apokalipsie? (Eng. Contemporary archaeological landscapes. What will we leave behind after the end of times?), Annales Universitatis Mariae Curie-Skłodowska, 34, 201-211.

Fenyk M.A., Kuszewska K., 2010, Flora opuszczonych sadyb gospodarskich Warmii (Eng. Flora of the abandoned 
farmsteads in the Warmia region), Acta Scientarium Polonorum, 9(2), 59-70.

Kobiałka D., Kostyrko M., Kajda K., 2015, Materialna pamięć krajobrazów: przykład niemieckiego obozu jenieckiego w Czersku, woj. pomorskie (część II) (Eng. Material memory of landscapes: an example of war camp in Czersk, pomeranian voivodeship), Biografia Archeologii, 1, 66-74.

Myga-Piątek U., 2015, Pamięć krajobrazu - zapis dziejów w przestrzeni (Eng. Landscape memory - the record of history in space), Studia Geohistorica, 3, 29-45.

Poyatos R., Latron J., Llorens P., 2003, Land Use and Land Cover Change after Agricultural Abandonement. The Case of Mediterranean Mountain Area (Catalan Pre-Pyrenees), Mountain Research and Development, 23(4), 362-368. doi: 10.1659/0276-4741(2003)023[0362:LUALCC]2.0.CO;2

Sobala M., 2012, Rola materiałów kartograficznych w wyznaczaniu granic obszaru badań zmian krajobrazu kulturowego (Eng. Cartographic materials and their important part in delimitation borders of examined region in changes of culture landscape), Prace Komisji Krajobrazu Kulturowego. Źródła kartograficzne w badaniach krajobrazu kulturowego, 16, 105-115.

Wardell D.A., Reenberg A., Tøttrup Ch., 2003, Historical footprints in contemporary land use systems: forest cover changes in savannah woodlands in the Sudano-Sahelian zone, Global Environmental Change, 13, 235-254. doi: 10.1016/S0959-3780(03)00056-6.

Wolski J. 2007, Przekształcenia krajobrazu wiejskiego Bieszczadów Wysokich w ciagu ostatnich 150 lat (Eng. Transformations of the High Bieszczady Mountains rural landscape during the last 150 years), Instytut Geografii i Przestrzennego Zagospodarowania PAN, Warszawa.

\section{Materials}

GUGiK: Główny Urząd Geodezji i Kartografii (Eng. Head Office of Land Surveying and Cartography), LAS data:

- N-34-75-B-a-3-2-2,

- N-34-79-B-a-2-3-1,

- N-34-66-B-b-2-4-4,

- N-34-78-D-c-4-2-2.

Ortophotomaps: Główny Urząd Geodezji i Kartografii - www. geoportal.gov.pl.

Satellite imagery: Google Earth: Landsat/Copernicus.

Topographische Karte Messtischblatt (1920s-1940s), 1:25,000, Königliche Preussische Landesaufnahme; Reichsamt für Landesaufnahme, Berlin.

Topographische Karte Messtischblatt, 1:25,000, sheets: 1695 - Nordenburg, 1933; 1797 - Buddern, 1927; 1694 - Wandlacken, 1940; 1788 - Landsberg, 1936, Königliche Preussische Landesaufnahme; Reichsamt für Landesaufnahme, Berlin. 